\title{
Treatment of diffuse diabetic maculopathy with intravitreal triamcinolone and laser photocoagulation: randomized clinical trial with morphological and functional evaluation
}

\author{
Tratamento da maculopatia diabética difusa com triancinolona intravítrea e fotocoagulação \\ a laser: ensaio clínico randomizado com avaliação morfofuncional
}

Alberto Luiz Gil ${ }^{1}$, Mirela Jobim de Azevedo² ${ }^{2}$ Giovani Generali Tomasetto ${ }^{1}$, Carlos Henrique Gervini Muniz ${ }^{1}$, Jacó Lavinsky ${ }^{1}$

\begin{abstract}
Purpose: Treatment of diffuse macular edema in diabetes mellitus is currently unsatisfactory. The purpose of this double blind randomized clinical trial was to compare the treatment of diffuse diabetic macular edema with intravitreal triamcinolone or laser in type 2 diabetes mellitus patients using a morphofunctional assessment. Methods: Fourteen patients (21 eyes) with clinically significant diffuse macular-edema, previously untreated and with a macular thickness $>250 \mu \mathrm{m}$ at optical coherence tomography were randomized for treatment with laser or intravitreal injection of triamcinolone acetate. Optical coherence tomography, biomicroscopy, fundoscopy, fluorescein angiography, tonometry, scotometry, visual and contrast acuities were performed at 0, 1, 3 and 6 months.

Results: At pre-treatment stage, Laser $(n=9)$ and Triamcinolone $(n=12)$ groups did not differ regarding retinal thickness, visual and contrast acuities. In Triamcinolone group macular thickness decreased after 1 month $(424.1 \pm 19.9 \mu \mathrm{m}$ to $358.4 \pm 18.2 \mu \mathrm{m}$ $p=0.04)$ and started to return to the initial values in the $3^{\text {rd }}$ month $(p=0.02)$. No changes occurred in macular scotometry and visual and contrast acuities. No side effects were observed with both treatments.

Conclusion: During the study macular thickness diminished in the triamcinolone group, especially in the first month of treatment. At 3 and 6 months there was no difference. Macular thickness did not change during the study in the laser group. In the study sample it was not possible to demonstrate differences relates to visual acuity and scotometry between the two groups.

ClinicalTrials.gov Identifier: NCT00668239
\end{abstract}

Keywords: Macular edema/drug therapy; Triamcinolone/therapeutic use; Photocoagulation; Diabetes mellitus; Tomography, Optical coherence

\section{RESUMO}

Objetivo: O tratamento do edema macular difuso diabético atualmente éinsatisfatório. O objetivo deste ensaio clínico randomizado duplo cego foi comparar, através de avaliaçãomorfofuncional, o tratamento do edema macular difuso diabético com triancinolona intravitrea ou laser em grade em pacientes com DM tipo 2.

Métodos: Quatorze pacientes (21 olhos) com edema macular difuso clinicamente significativo, sem tratamento prévio e com espessura macular $>250 \mu$ mà tomografia de coerência óptica (OCT) foram randomizados para tratamento com laser ou injeção intravitrea de acetato de triancinolona. Nos tempos 0, 1, 3 e 6 meses foram realizados OCT, biomicroscopia, fundoscopia, angiografia fluoresceínica, tonometria, escotometria, acuidade visual e de contraste.

Resultados: Na fase pré-tratamento, os grupos Laser ( $n=9)$ e Triancinolona ( $n=12)$ não diferiram na espessura retiniana, escotometria, acuidade visual e de contraste. No grupo Triancinolona houve redução da espessura macular após 1 mês $(424,1 \pm 19,9 \mu \mathrm{m}$ vs. $358,4 \pm 18,2 \mu \mathrm{m} ; P=0,04)$ com retorno aos valores iniciais a partir do mês $3(P=0,02)$. Não houve modificação significativa na escotometria macular, acuidade visual e de contraste. Não ocorreram efeitos colaterais nos tratamentos.

Conclusão: Durante o estudo observou-se diminuição da espessura macular no grupo tratado com triancinolona, principalmente no primeiro mês de tratamento. Aos 3 e 6 meses de tratamento não houve diferença. A espessura macular não modificou durante o estudo no grupo tratado com laser. Nesta amostra estudada não foi possível demonstrar diferenças relacionadas à escotometria e acuidade visual entre os dois grupos.

Descritores: Edema macular/quimioterapia; Triancinolona/uso terapêutico; Fotocoagulação; Diabetes mellitus; Tomografia de coerência óptica

\section{INTRODUCTION}

Diabetic retinopathy (DR) is the main cause of visual loss in adults. Macular edema affects 29\% of the patients with DR and is the main cause of visual loss in this population ${ }^{(1,2)}$.

The Early Treatment Diabetic Retinopathy Study (ETDRS) ${ }^{(2)}$ showed a major benefit of treatment with laser photocoagulation of clinically significant macular edema. Although this treatment reduces moderate visual loss by $50 \%$, about $24 \%$ of treated eyes presented a thickened macula and consequently diminished sight after 36 months, suggesting that there is a subset of patients who are resistant to laser photocoagulation treatment.
Prior studies assessing patients with diabetic retinopathy showed that laser treatment of eyes with diffuse macular edema had a worse result than eyes with focal macular edema ${ }^{(3)}$, raising interest in other therapeutic options including surgery, with pars plana vitrectomy, pharmacological treatment with protein kinase $C$ inhibitors ${ }^{(4)}$, and intraocular corticosteroids.

Corticosteroids treatment for ophthalmological diseases are being studied $^{(5)}$ and used intravitreally in different diseases ${ }^{(6)}$. Among the related adverse effects are transient increased intraocular pressure ${ }^{(5,7)}$, corticogenic glaucoma ${ }^{(8)}$, retinal detachment, and infectious endophthalmitis, the latter with an incidence of 0 to $2.3 \%{ }^{(9)}$.
Submitted for publication: November 29, 2010

Accepted for publication: October 7, 2011

Study carried out at the Hospital de Clínicas de Porto Alegre, Porto Alegre (RS), Brazil.

Physician, Serviço de Oftalmologia do Hospital de Clínicas de Porto Alegre, Porto Alegre (RS), Brazil.

2 Physician, Serviço de Endocrinologia do Hospital de Clínicas de Porto Alegre, Porto Alegre (RS), Brazil.
Funding: This study was partially funded by FIPE - Hospital de Clínicas de Porto Alegre.

Disclosure of potential conflicts of interest: A.L.Gil, None; M.J.de Azevedo, None; G.G.Tomasetto, None; C.H.G.Muniz, None; J.Lavinsky, None.

Correspondence address: Alberto Luiz Gil. Rua Soledade, 569 - Conj. 905 A - Porto Alegre (RS) 90470-340 - Brazil - E-mail: albertogil@brturbo.com.br 
Some studies presented good results using intravitreal triamcinolone acetate to treat diffuse diabetic macular edema in patients who did not have a significant improvement with laser photocoagulation (conventional treatment)(10-15). Most of these studies did not describe the clinical characteristics of the patients studied(11,12,14,15). On the other hand, data about possible improvement using laser after intravitreal triamcinolone are controversial $\left.\right|^{(16,17)}$. A single noncontrolled study with a high dose of intravitreal triamcinolone (25 mg) assessed this injection as a primary treatment for diabetic macular edema ${ }^{(18)}$

Most studies with triamcinolone and laser photocoagulation consider visual acuity as an outcome parameter, thus evaluating especially foveal function. It is likely that a more complete evaluation of macular morphological and functional aspects will supply further information about the results of these treatments. Few aspects of diffuse diabetic maculopathy treatment have not yet been definitively established, such as, the best method of treatment and the correlation between morphological and functional results. It has also not been defined whether the evaluation of functional results should be done by analysis of foveal function or of the whole macula, using other tools such as macular sensitivity and contrast.

The purpose of this study was to compare the treatment of diffuse diabetic macular edema with intravitreal triamcinolone acetate or grid laser in patients with type 2 diabetes mellitus (DM) using a morphofunctional evaluation.

\section{METHODS}

\section{Patients}

In this double blind randomized clinical trial against active treatment, patients with type 2 DM and diffuse macular edema secondary to DR were evaluated between September 2004 and June 2006. Consecutively included patients were attended in the Center of Reference for Diabetic Retinopathy at Hospital de Clinicas de Porto Alegre (HCPA) and at the Ophthalmology Outpatient Clinic of HCPA.

The following inclusion criteria were considered: age greater than or equal to 30 years; DR with clinically significant diffuse macular edema, according to criteria established by ETDRS(2); no prior treatment with laser and/or intravitreal injection of triamcinolone acetate, and presence of central fixation, demonstrated in the Optical Coherence Tomography (OCT). Exclusion criteria were: history of glaucoma or ocular hypertension; intraocular surgery in the six preceding months; opacities of the cornea, lens or vitreous which would prevent performing laser or ophthalmological examinations; proliferative diabetic retinopathy; history of allergy to fluorescein or corticosteroids, and serum creatinine $>2.5 \mathrm{mg} / \mathrm{dl}$.

Type 2 DM was diagnosed in patients who had more than 30 years old at the diagnosis of DM with no previous episodes of ketoacidosis, and no insulin treatment in the first 5 years after DM diagnosis. All patients underwent a clinical and laboratory assessment before treatment, which included clinical history, blood pressure measurements, fasting blood glucose (glucose-peroxidase colorimetric enzymatic method- Biodiagnostica Kit, Roche Diagnóstica, São Paulo, Brazil), glycosilated hemoglobin [A1C test; High Performance Liquid Chromatography (HPLC) in a Merck-Hitachi ${ }^{\circledR}$ (Darmstadt, Germany) 9100 apparatus; Reference values 4.8-6.0\%], and serum creatinine (Jaffé reaction) measurements.

\section{Ophthalmological assessment}

The ophthalmological assessment consisted of: OCT, visual acuity, contrast acuity, scotometry, fluorescein angiography, intraocular pressure measurement, indirect fundoscopy, and biomicroscopy. After this evaluation patients were randomized to two treatment groups: triamcinolone or laser. New clinical, laboratory and ophthalmological evaluations were performed after one, three and six months.
In order to perform OCT, images of the retinal layers were obtained, comprising the $6 \mathrm{~mm}$ in the center of the macula in nine concentric measures. The examination was performed by the same investigator and at the same time (between 10 a.m. and 11 a.m.). The OCT (Stratus 3, Carl Zeiss ${ }^{\circledR}$, Oberkochen, Germany) was performed by an examiner who did not know the type of treatment to which the patient was submitted (G.T.). The Macular Thickness program was used to analyse macular thickness, using in the analysis the highest obtained measurement (peak) in each assessment. The patient's fixation (central or excentric) was determined. Visual acuity was measured with a table standardized by ETDRS, with improved correction of refraction ${ }^{(2)}$. Contrast was evaluated in a manner similar to visual acuity, using the Pelly-Robson table. The Humphrey All 745 [Carl Zeiss ${ }^{\circledR}$, Oberkochen, Germany, (4) with operational system 12.6] was used for scotometry (visual field 10-2). Visual acuity and scotometry were evaluated by an investigator who did not know the randomization group (C.M.). The camera used for fluorescein angiography was FF450 PLUS IR (Carl Zeiss ${ }^{\circledR}$, Oberkochen, Germany). Tonometry was performed on both eyes using the Perkins tonometer. Lens opacity was evaluated using the table LOCS II.

\section{TREATMENT GROUPS}

Laser treatment: argon laser (Crystal Focus - EMERED ${ }^{\circledR}$, Jena, Germany) was applied to the macular region according to the modified grid technique in inverted C, preserving $500 \mu$ of the foveolus and avascular zone, with $100 \mu$ diameter shots, energy varying from 0.2 to 0.5 joules, with a exposure time between 0.2 and 0.4 seconds. One hundred and fifty to 200 shots were applied according to the retinal area size ${ }^{(2)}$.

Laser for masking (sham procedure): the same stages used for laser treatment were performed, but energy was set to zero, resulting in a simulation of the treatment.

Triamcinolone treatment: $0.1 \mathrm{ml}(4 \mathrm{mg}$ ) of triamcinolone acetate intravitreous was injected through the pars plana in a surgical environment. The medication used was manipulated by the Ophthalmos chemist without a preservative agent.

Triamcinolone for masking: the same stages used for triamcinolone acetate injection were performed in a surgical environment and the simulation of the injection was done by minimum pressure in the patient's conjunctiva using the capped needle.

\section{Statistical analysis}

The sample size was calculated considering the main outcome, retinal thickness, measured by OCT before and after treatment. Assuming a mean reduction of the macular edema of $100 \mu \mathrm{m}^{(19)}$ after laser and a reduction of $250 \mu \mathrm{m}^{(12)}$ after intravitreal injection, to have a $90 \%$ power and 0.05 alpha, an estimative of 8 eyes for each treatment group (difference of $150 \mu \mathrm{m}$ ) had to be included.

Paired and non-paired t tests were used for comparison purposes, as indicated. ANOVA for repeat measures followed by a multiple comparison test, LSD (least significant difference) was used to analyse morphofunctional changes of the macula and clinical variables during the study. Systolic and diastolic blood pressure changes were used as covariates to analyse the ophthalmological variables at the different evaluation times.

Data were expressed as mean \pm standard deviation, as a percentage of patients with the characteristic, or as means (95\% confidence interval). $P$ values $<0.05$ were considered statistically significant. Statistical analysis was performed using SPSS 14.0 (SPSS ${ }^{\circledR}$, Chicago, IL, USA).

\section{Ethics}

The study protocol was approved by the Ethics Committee/Investigational Review Board of HCPA and free and informed consent was obtained from all patients. 


\section{RESULTS}

Fourteen patients with type 2 DM and DR fulfilled the inclusion criteria and agreed to participate in the study. Four male and 10 female patients, aged $59.3 \pm 6.0$ years (52 to 67 years) with DM duration of $15.0 \pm 7.3$ years (5 to 28 years) were assessed. Two of these patients were being treated with intermediate action insulin, five were using anti-hyperglycemic drugs (metformin, glibenclamide) and six patients, insulin and anti-hyperglycemic drugs. All patients were hypertensive and used enalapril maleate. Two patients, one in each treatment group, also used hydrochlorothiazide. No medication was changed or included during the study.

Seven patients were randomized to treatment with triamcinolone and seven to laser treatment. Twenty-one eyes were studied: 19 with non-proliferative moderate DR and two with non-proliferative severe DR. Seven patients were treated in both eyes: five patients in the Triamcinolone group and two patients in the Laser group.

Table 1 describes clinical and laboratory evaluated parameters before treatment and in the $1^{\text {st }}, 3^{\text {rd }}$, and $6^{\text {th }}$ month. These features were compared between the patients of the Triamcinolone group and the Laser group in the beginning of the study: systolic blood pressure, diastolic blood pressure, fasting blood glucose, AIC test, and serum creatinine and were not different among the two groups.

During the study, systolic blood pressure increased in the group treated with triamcinolone. End-of-study diastolic blood pressure values were higher than pre-treatment values in both groups. Fasting blood glucose, AIC test, and serum creatinine did not change during the study in the Triamcinolone and Laser groups.

Table 2 shows the ophthalmological parameters before treatment and after 1, 3, and, 6 months.

Macular thickness, scotometry, visual and contrast acuity measurements, and intraocular pressure were not different in the Triamcinolone and Laser groups in the pre-treatment period. The analysis of OCT measurements during the study was adjusted to systolic and diastolic blood pressure changes (delta) from baseline to the end-of-study. During the study macular thickness diminished in the Triamcinolone group. This reduction was observed in the first month of treatment. At the $3^{\text {rd }}$ and $6^{\text {th }}$ months there was no difference in the macular thickness as compared to pre-treatment values. Considering the absolute values of retinal thickness obtained in OCT minus the reference value of retinal thickness $(206 \mu \mathrm{m})$, the reduction observed in the $1^{\text {st }}$ month of treatment with triam- cinolone was $30.1 \pm 2.0 \%$. The macular thickness returned to the pre-treatment value with recurrence of macular edema that started in the $3^{\text {rd }}$ month. Macular thickness did not change during the study in the Laser group.

Visual and contrast acuities and intraocular pressure were not evaluated at the end-of-study in all patients due to non-compliance with schedules after end-of-study OCT was performed. Those exams did not change during the study in both treatment groups. In the Triamcinolone group the improvement of macular sensitivity in the $3^{\text {rd }}$ month, as evaluated by scotometry, did not attain the statistical adopted significance.

In both treatment groups no patient developed cataract, uveitis, vitreitis, retinal detachment, endophthalmitis, or any possibly treatment related side effects.

\section{DISCUSSION}

In this study, the eyes of patients with type 2 DM and diffuse macular edema treated with intravitreal triamcinolone had a greater retinal thickness reduction in the $1^{\text {st }}$ month post-treatment as compared to the eyes treated with laser photocoagulation. This retinal thickness improvement observed with triamcinolone treatment remained up to the $3^{\text {rd }}$ month of the study. Subsequently, the macular edema recurred in all patients.

The morphological evaluation of the macula was performed by $\mathrm{OCT}$, enabling retinal layers visualization. This methodology has a resolution close to that of histology, and allows quantification of the macular thickness. In addition, all measurements were performed at the same time of the day to avoid diurnal variation of retinal thickness. This procedure, associated with the masking of the investigators and patients, ensured accurate evaluation of retinal edema.

In patients with DM and diffuse macular edema, the use of triamcinolone alone was evaluated in a single study ${ }^{(18)}$. Despite favourable results in OCT and visual acuity in this non-controlled study, a much higher triamcinolone dose was used as compared to the present study (25 mg vs. 4 mg). Furthermore, a major increase in intraocular pressure that required surgery was observed in 13\% of the patients. Only a recently published study compared the results of intravitreal triamcinolone, laser or both treatments ${ }^{(17)}$. In the combined treatment group, the laser was performed 30 days after intravitreal injection of triamcinolone. The results reported were similar to those of the present study, with improved retinal thickness

Table 1. Clinical and laboratory characteristics of the groups treated with triamcinolone and laser during the study

\begin{tabular}{|c|c|c|c|c|c|c|}
\hline & $\mathbf{N}$ & Pre-treatment & 1 month & 3 months & 6 months & $\mathbf{p}^{\mathrm{a}}$ \\
\hline \multicolumn{7}{|l|}{$\mathrm{SBP}(\mathrm{mmHg})$} \\
\hline Triamcinolone & 7 & $135.7 \pm 9.8$ & $137.1 \pm 11.1$ & $148.6 \pm 12.1$ & $154.3 \pm 19.0$ & $0.004^{b}$ \\
\hline Laser & 7 & $137.1 \pm 7.6$ & $145.7 \pm 11.3$ & $154.3 \pm 18.1$ & $158.6 \pm 21.2$ & 0.059 \\
\hline \multicolumn{7}{|l|}{$\mathrm{DBP}(\mathrm{mmHg})$} \\
\hline Triamcinolone & 7 & $80.0 \pm 5.8$ & $80.0 \pm 5.8$ & $87.1 \pm 4.9$ & $90.0 \pm 11.6$ & 0.008 \\
\hline Laser & 7 & $83.6 \pm 7.5$ & $89.3 \pm 8.4$ & $91.4 \pm 10.7$ & $96.4 \pm 9.4$ & $0.044^{d}$ \\
\hline \multicolumn{7}{|l|}{ Glycemia (mg/dl) } \\
\hline Triamcinolone & 7 & $214.5 \pm 52.8$ & $202.3 \pm 54.4$ & $191.8 \pm 51.5$ & $193.3 \pm 41.4$ & 0.231 \\
\hline Laser & 7 & $201.2 \pm 56.0$ & $194.0 \pm 38.2$ & $200.8 \pm 50.2$ & $188.0 \pm 33.7$ & 0.656 \\
\hline \multicolumn{7}{|l|}{$\mathrm{A} 1 \mathrm{C}$ test $(\%)$} \\
\hline Triamcinolone & 7 & $8.8 \pm 1.6$ & $8.9 \pm 2.0$ & $8.9 \pm 1.9$ & $9.3 \pm 2.3$ & 0.458 \\
\hline Laser & 7 & $8.1 \pm 1.6$ & $8.3 \pm 1.7$ & $8.1 \pm 1.7$ & $7.9 \pm 1.6$ & 0.202 \\
\hline \multicolumn{7}{|l|}{ Creatinine (mg/dl) } \\
\hline Triamcinolone & 7 & $0.88 \pm 0.26$ & $0.92 \pm 0.25$ & $0.87 \pm 0.22$ & $0.95 \pm 0.30$ & 0.140 \\
\hline Laser & 7 & $0.70 \pm 0.13$ & $0.68 \pm 0.12$ & $0.72 \pm 0.12$ & $0.68 \pm 0.12$ & 0.317 \\
\hline
\end{tabular}

$\mathrm{SBP}=$ systolic blood pressure; $\mathrm{DBP}=$ diastolic blood pressure

a =ANOVA for repeated measures ${ }^{b}=$ multiple comparison test: LSD (Least Significant Difference) $p=0.049$ for pre-treatment vs. 3 months, $p=0.021$ for pre-treatment vs. 6 months, $p=0.047$ for 1 vs. 3 months, $p=0.017$ for 1 vs. 6 months; $=$ multiple comparison test: LSD (Least Significant Difference) $p=0.047$ for pre-treatment vs. 3 months, $p=0.038$ for pre-treatment vs. 6 months;

${ }^{d}=$ multiple comparison test: LSD (Least Significant Difference) $p=0.047$ for pre-treatment vs. 1 month, $p=0.038$ for pre-treatment vs. 6 months 
Table 2. Ophthalmological characteristics of the groups treated with triamcinolone and laser during the study

\begin{tabular}{|c|c|c|c|c|c|c|}
\hline & $\mathbf{N}$ & Pre-treatment & 1 month & 3 months & 6 months & $\mathbf{p}^{\mathrm{a}}$ \\
\hline \multicolumn{7}{|l|}{$\mathrm{OCT}(\mu \mathrm{m})$} \\
\hline Triamcinolone & 12 & $424.1 \pm 19.9$ & $358.4 \pm 18.2$ & $420.50 \pm 33.77$ & $424.5 \pm 29.1$ & $0.013^{b}$ \\
\hline Laser & 9 & $380.4 \pm 32.2$ & $366.1 \pm 36.6$ & $332.20 \pm 27.50$ & $348.4 \pm 35.8$ & 0.132 \\
\hline \multicolumn{7}{|l|}{ Scotometry (dB) } \\
\hline Triamcinolone & 11 & $-136.3 \pm 100.8$ & - & $-91.4 \pm 48.7$ & - & 0.073 \\
\hline Laser & 4 & $-151.0 \pm 157.0$ & - & $-95.5 \pm 46.5$ & - & 0.498 \\
\hline \multicolumn{7}{|c|}{ Visual acuity (ETDRS) } \\
\hline Triamcinolone & 10 & $0.97 \pm 0.30$ & - & $0.84 \pm 0.14$ & - & 0.096 \\
\hline Laser & 6 & $0.72 \pm 0.25$ & - & $0.73 \pm 0.34$ & - & 0.842 \\
\hline \multicolumn{7}{|c|}{ Contrast (Pelly-Robson) } \\
\hline Triamcinolone & 10 & $0.93 \pm 0.29$ & - & $1.10 \pm 0.24$ & - & 0.170 \\
\hline Laser & 3 & $0.90 \pm 0.26$ & - & $1.14 \pm 0.20$ & - & 0.721 \\
\hline \multicolumn{7}{|c|}{ Intraocular pressure $(\mathrm{mmHg})$} \\
\hline Triamcinolone & 12 & $13.4 \pm 1.8$ & $12.5 \pm 1.6$ & $13.0 \pm 2.1$ & $13.0 \pm 1.6$ & 0.541 \\
\hline Laser & 9 & $12.1 \pm 1.5$ & $12.7 \pm 0.9$ & $12.1 \pm 0.9$ & $12.4 \pm 1.1$ & 0.471 \\
\hline
\end{tabular}

OCT= optical coherence tomography

${ }^{a}=$ ANOVA for repeated measures with systolic and diastolic blood pressure as covariates ${ }^{b}=$ multiple comparison test: LSD (Least Significant Difference) $p=0.040$ for pre-treatment vs. 1 month, $p=0.020$ for 1 vs. 3 months, $p=0.025$ for 1 vs. 6 months

only in the patients who received triamcinolone. However, about $40 \%$ of the patients had been treated with photocoagulation before they entered the study. Moreover, the authors studied patients with type 1 and type 2 DM and did not supply any information about glycemic and blood pressure control of the patients. The overall macular function was not evaluated and foveal function was evaluated by visual acuity.

The recurrence of increased retinal thickness in all patients, observed after the $3^{\text {rd }}$ month, was probably related to poor metabolic and blood pressure control of studied patients. Indeed, the mean values of AIC test (>8.8\%) were above those usually recommended ${ }^{(20)}(<7 \%)$. Furthermore, during the study the patients presented a significant increase in blood pressure values unrelated to the change in their anti-hypertensive treatment. It is well known that poor glycemic and pressure control is a risk factor for diabetic maculopathy ${ }^{(21)}$. However, this sample of patients is probably representative of most diabetic patients seen in outpatient routine. Poor glycemic and blood pressure control is observed both in developing countries like Brazil(22) and in developed countries ${ }^{(23)}$. The influence of glycemic and pressure control in diabetic maculopathy is reinforced by the observation that in studies that demonstrated a more lasting effect (six months) of intravitreal triamcinolone, the patients had better metabolic and blood pressure contro| $\left.\right|^{(11,12,14,15)}$.

No improvement was seen in visual acuity as evaluated by the ETDRS Table in the patients of the Triamcinolone group or the Laser group. Other authors also observed improved macular edema without improved visual acuity using triamcinolone ${ }^{(12,13)}$. These findings can probably be accounted for by the damage caused to the foveal cells as a result of edema and serous detachment (maculaoff). In this sense, other overall methods to evaluate the macula (sensitivity to contrast using the Pelly-Robson Table and macular scotometry) should also be used. In the present study, the posttriamcinolone recovery of macular sensitivity measured by scotometry was about 34\%, but this improvement had borderline statistical significance. All the patients whose scotometry improved also presented a reduction in the retinal thickness evaluated by OCT (Figure 1). However, probably because not all patients underwent scotometry, there was no statistical proof of this morphofunctional association with the response to treatment with triamcinolone.

The triamcinolone dose used, 4 mg intravitreally, did not cause increased intraocular pressure in the present study. It has already been shown that probably there was not any advantage in using high triamcinolone doses ${ }^{(24)}$. Furthermore, intraocular pressure increase of 20 to $80 \%$ may also occur independent of the triamcino-
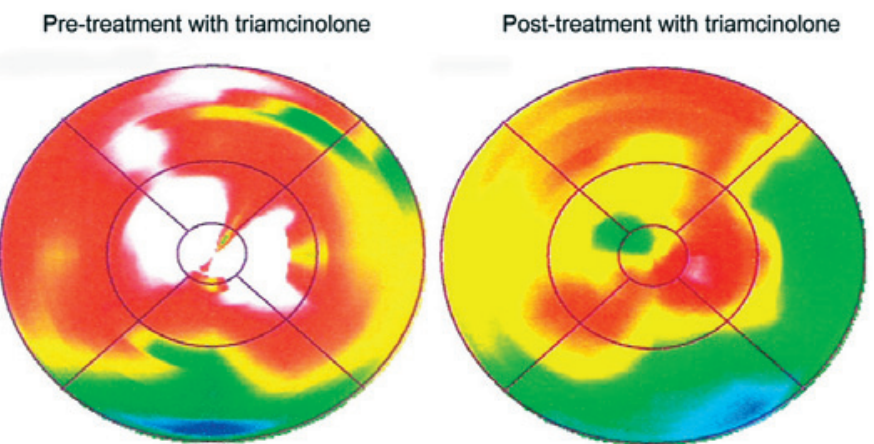

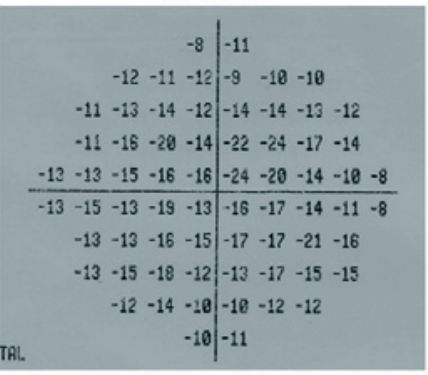

Visual acuity: 1.0

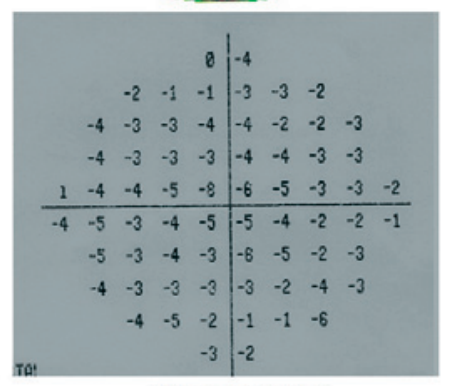

Visual acuity: 0.8
Figure 1. Morphological and functional evaluation with triamcinolone treatment.

lone dose used ${ }^{(5,7,12,13)}$. Possibly in the present study the use of triamcinolone manipulated without any addition of preservatives agents may have contributed to the absence of this complication. Also, no progression or onset of cataract, or other complications related to intravitreal injection, such as retinal detachment or endophthalmitis, were observed in the eyes studied.

Among the possible limitations of this study is the number of patients evaluated. Moreover, scotometry could not be performed in all patients. This fact probably accounts for the non-statistical significance in the improvement in macular sensitivity. However, the design used and the adoption of treatment simulation, both for triamcinolone and for laser treatments, support the importance of the present data. This study should be expanded with a greater number of patients and the correlation of macular function with retinal thickness confirmed. 
Short duration treatment with triamcinolone was effective and safe in this sample of patients with type $2 \mathrm{DM}$. It is likely that to prolong the beneficial effects of triamcinolone, intensified glycemic and blood pressure control should be part of the treatment of diffuse diabetic maculopathy. The alternative of using laser after intravitreal triamcinolone is still controversial ${ }^{(16,17)}$ and it must be evaluated in well-designed clinical trials. The possibility of association with other pharmaceuticals used intravitreally, such as the anti-VEGFs (pegaptanib sodium), may also be a therapeutic alternative to improve the results of the treatment of diabetic maculopathy ${ }^{(25)}$.

During the study macular thickness diminished in the triamcinolone group, especially in the first month of treatment. At 3 and 6 months there was no difference. Macular thickness did not change during the study in the laser group. In the study sample it was not possible to demonstrate differences related to visual acuity and scotometry between the two groups.

\section{ACKNOWLEDGEMENTS}

The triamcinolone used for intravitreal injection was supplied by "Opthalmos - Farmácia de Manipulação", Porto Alegre, RS, Brazil and OCT exams were performed at "Instituto de Oftalmologia Lavinsky" - Porto Alegre (RS), Brazil.

\section{REFERENCES}

1. Klein R, Klein BE, Moss SE, Davis MD, DeMets DL. The Wisconsin epidemiologic study of diabetic retinopathy. IV. Diabetic macular edema. Ophthalmology. 1984;91(12):1464-74.

2. Photocoagulation for diabetic macular edema. Early Treatment Diabetic Retinopathy Study report number 1. Early Treatment Diabetic Retinopathy Study research group. Arch Ophthalmol. 1985;103(12):1796-806

3. Bresnick GH. Diabetic macular edema. A review. Ophthalmology. 1986:93(7):989-97.

4. Pendergast SD, Hassan TS, Williams GA, Cox MS, Margherio RR, Ferrone PJ, et al. Vitrectomy for diffuse diabetic macular edema associated with a taut premacular posterior hyaloid. Am J Ophthalmol. 2000;130(2):178-86.

5. Antcliff RJ, Spalton DJ, Stanford MR, Graham EM, ffytche TJ, Marshall J. Intravitreal triamcinolone for uveitic cystoid macular edema: an optical coherence tomography study. Ophthalmology. 2001;108(4):765-72.

6. Greenberg PB, Martidis A, Rogers AH, Duker JS, Reichel E. Intravitreal triamcinolone acetonide for macular edema due to central retinal vein occlusion. Br J Ophthalmol. 2002; 86(2):247-8.

7. Jonas JB, Kreissig I, Degenring R. Intraocular pressure after intravitreal injection of triamcinolone acetonide. Br J Ophthalmol. 2003;87(1):24-7.

8. KaushikS, Gupta V, Gupta A, Dogra MR, Singh R. Intractable glaucoma following intravitreal triamcinolone in central retinal vein occlusion. Am J Ophthalmol. 2004;137(4):758-60.
9. Moshfeghi DM, Kaiser PK, Scott IU, Sears JE, Benz M, Sinesterra JP, et al. Acute endophthalmitis following intravitreal triamcinolone acetonide injection. Am J Ophthalmol. 2003; 136(5):791-6. Comment in Am J Ophthalmol. 2004;137(6):1158-9; author reply 1160-1. Am J Ophthalmol. 2004;137(6):1159-60; author reply 1160-1. Am J Ophthalmol. 2004;137(6):1166; author reply 1167. Am J Ophthalmol. 2003;136(5):918-9.

10. Jonas JB, Kreissig I, Söfker A, Degenring RF. Intravitreal injection of triamcinolone for diffuse diabetic macular edema. Arch Ophthalmol. 2003;121(1):57-61.

11. Audren F, Erginay A, Haouchine B, Benosman R, Conrath J, Bergmann JF, et al. Intravitreal triamcinolone acetonide for diffuse diabetic macular edema: 6-month results of a prospective controlled trial. Acta Ophthalmol Scand. 2006;84(5):624-30.

12. Martidis A, Duker JS, Greenberg PB, Rogers AH, Puliafito CA, Reichel E, Baumal C. Intravitreal triamcinolone for refractory diabetic macular edema. Ophthalmology. 2002;109(5):920-7.

13. Jonas JB, Spandau UH, Kamppeter BA, Vossmerbauemer U, Harder B. Follow-up after intravitreal triamcinolone acetonide for diabetic macular edema. Eur J Ophthalmol. 2006; 16(4):566-72.

14. Massin P, Audren F, Haouchine B, Erginay A, Bergmann JF, Benosman R, et al. Intravitreal triamcinolone acetonide for diabetic diffuse macular edema: preliminary results of a prospective controlled trial. Ophthalmology. 2004;111(2):218-24; discussion 224-5.

15. Gillies MC, Sutter FK, Simpson JM, Larsson J, Ali H, Zhu M. Intravitreal triancinolone for refractory diabetic macular edema: two-year results of a double-masked, placebo-controlled, randomized clinical trial. Ophthalmology. 2006;113(9):1533-8.

16. Kang SW, Sa HS, Cho HY, Kim Jl. Macular grid photocoagulation after intravitreal triamcinolone acetonide for diffuse diabetic macular edema. Arch Ophthalmol. 2006;124(5): 653-8.

17. Lam DS, Chan CK, Mohamed S, Lai TY, Lee VY, Liu DT, et al. Intravitreal triamcinolone plus sequential grid laser versus triamcinolone or laser alone for treating diabetic macular edema: six-month outcomes. Ophthalmology. 2007;114(12):2162-7.

18. Nicolò M, Nasciuti F, Lai S, Ghiglione D, Borgia L, Calabria G. Intravitreal triamcinolone acetonide as primary treatment for diffuse diabetic macular edema: a prospective noncomparative interventional case series. Eur J Ophthalmol. 2006;16(1):129-33.

19. Lattanzio R, Brancato R, Pierro L, Bandello F, laccher B, Fiore T, Maestranzi G. Macular thickness measured by optical coherence tomography $(\mathrm{OCT})$ in diabetic patients. Eur $\mathrm{J}$ Ophthalmol. 2002;12(6):482-7.

20. American Diabetes Association. Standards of medical care in diabetes-2007. Diabetes Care. 2007;30 Suppl 1:S4-S41.

21. Stratton IM, Kohner EM, Aldington SJ, Turner RC, Holman RR, Manley SE, Matthews DR UKPDS 50: risk factors for incidence and progression of retinopathy in Type II diabetes over 6 years from diagnosis. Diabetologia. 2001;44(2):156-63.

22. Gomes MB, Gianella D, Faria M, Tambascia M, Fonseca RM, Réa R, et al. Prevalence of Type 2 diabetic patients within the targets of care guidelines in daily clinical practice: a multicenter study in Brazil. Rev Diabet Stud. 2006;3(2):82-7.

23. Saydah SH, Fradkin J, Cowie CC. Poor control of risk factors for vascular disease among adults with previously diagnosed diabetes. JAMA. 2004;291(3):335-42.

24. Lam DS, Chan CK, Mohamed S, Lai TY, Li KK, Li PS, et al. A prospective randomised trial of different doses of intravitreal triamcinolone for diabetic macular edema. Br J Ophthalmol. 2007;91(2):199-203

25. Funatsu H, Yamashita H, Ikeda T, Nakanishi Y, Kitano S, Hori S. Angiotensin II and vascular endothelial growth factor in the vitreous fluid of patients with diabetic macular edema and other retinal disorders. Am J Ophthalmol. 2002;133(4):537-43. 